Jurnal Informatika dan Rekayasa Perangkat Lunak (JATIKA)
Vol. 1, No. 2, December 2020, 234-244
ISSN 2723-3367
available online at:http:///im.teknokrat.ac.id/index.php/informatika

\title{
PERANCANGAN APLIKASI GAME FIGHTING 2 DIMENSI DENGAN TEMA KARAKTER NUSANTARA BERBASIS ANDROID MENGGUNAKAN CONSTRUCT 2
}

\author{
Reno Rinaldi Pradana ${ }^{1}$, Ade Surahman ${ }^{2}$ \\ Universitas Teknokrat Indonesia ${ }^{\mathbf{1 , 2}}$ \\ RenoRinaldiPradana@gmail.com¹, adesurahman@teknokrat.ac.id ${ }^{2}$
}

\begin{abstract}
Received: (30 Desember 2020)Accepted: (31 Desember 2020) Published: (31 Desember 2020)
Abstract

Games are one of the entertainment media that is in great demand by the public, from early childhood to adults. In general, the game is divided into 7 (seven) types, namely, RTS (Real Time Strategy), FPS (First Person Shooter), RPG (Role Playing Game), Construction and Management Simulation Games, Vehicle Simulation, Action, Adventure and Fighting. In this study, adesigned fighting game was with the theme of Indonesian characters. In addition to being a medium of entertainment, game thisaims to introduce traditional clothes and weapons for men from 10 provinces on the island of Sumatra, using construct 2 as the game engine. The design game uses the development method Multimedia Development Life Cycle (MDLC) which consists of 6 stages, namely, Concept, Design, Obtaining Content Material, Assembly, Testing, and Distribution. Thisapplication game was tested using ISO 9126 testing, with the results of testing aspects of functionality of $98.67 \%$, efficiency of $98.22 \%$, usability of $98.00 \%$, and portability of $100.00 \%$. The total percentage of ISO 9126 testing for the quality ofgame software thisis $98.75 \%$ which is considered very feasible.
\end{abstract}

Keywords: Adventure, Fighting, Games, ISO 9126, MDLC.

\begin{abstract}
Abstrak
Game merupakan salah satu media hiburan yang banyak diminati oleh kalangan masyarakat, dari anak usia dini hingga orang dewasa. Secara umum game dibagi menjadi 7 (tujuh) jenis yang diterapkan yaitu, RTS (Real Time Strategy), FPS (First Person Shooter), RPG (Role Playing Game), Construction and Management Simulation Games, Vehicle Simulation, Action, Adventure dan Fighting. Dalam penelitian ini dilakukan perancangan sebuah game fighting dengan tema karakter nusantara. Selain menjadi media hiburan, game ini bertujuan untuk memperkenalkan pakaian dan senjata adat laki-laki dari 10 provinsi yang ada di pulau Sumatradengan menggunakan construct 2sebagai engine game. Perancangan game menggunakan metode pengembangan Multimedia Development Life Cycle (MDLC) yang terdiri dari 6 tahap yaitu, Concept, Design, Obtaining Content Material, Assembly, Testing, dan Distribution. Aplikasi game ini diuji mengunakan pengujian ISO 9126, dengan hasil pengujian aspek functionality sebesar 98,67\%, efficiency sebesar 98,22\%, usability sebesar 98,00\%, dan portability sebesar 100,00\%. Presentase total dari pengujian ISO 9126 untuk kualitas software game ini adalah $98,75 \%$ yang dinyatakan sangat layak.
\end{abstract}

Kata Kunci: Adventure, Fighting, Games, ISO 9126, MDLC.

\section{To cite this article:}

Reno Rinaldi Pradana, Ade Surahman. (2020). PERANCANGAN APLIKASI GAME FIGHTING 2 DIMENSI DENGAN TEMA KARAKTER NUSANTARA BERBASIS ANDROID MENGGUNAKAN CONSTRUCT 2. Jurnal Informatika dan Rekayasa Perangkat Lunak, $\operatorname{Vol}(1) \operatorname{No}(2), 234-244$.

\section{PENDAHULUAN}

Saat ini perkembangan teknologi sangat pesat. Fenomena ini juga akan mempengaruhi perkembangan game. Saat game mulai muncul, hanya satu atau dua orang yang dapat menggunakan konsol game untuk 
memainkan game tersebut, dan media tampilan harus tetap menggunakan TV. Namun, saat ini, game berkembang seiring dengan pertumbuhan pengetahuan dan kreativitas manusia (Sintaro, Ramdani and Samsugi, 2020). Sekarang, semakin banyak pengembang game bermunculan, dari individu hingga perusahaan besar yang berfokus pada pengembangan game. Media yang digunakan pun semakin beragam, mulai dari personal computer (PC) hingga perangkat Android yang sedang populer (Christiantho, 2017; Ahdan and Setiawansyah, 2020).

Game dibedakan menjadi beberapa jenis yaitu berdasarkan platform yang digunakan, ukuran dan jenis game itu sendiri. Jenis dalam game menunjukkan mode umum tantangan dalam game. Dengan perkembangan informasi saat ini jenis-jenis permainan masih terus berkembang, namun secara umum permainan dapat dibedakan menjadi 7 (tujuh) jenis yaitu RTS (real-time strategy), FPS (first-person shooting), dan RPG (role-playing game). Game simulasi konstruksi dan manajemen, game simulasi kendaraan, aksi, petualangan, dan pertempuran adalah kompetisi atau simulasi yang sama dengan game lainnya. Jenis permainan ini tidak dapat memberikan proses mengelola atau mengalahkan musuh melalui strategi dan taktik. Game petualangan adalah cerita interaktif tentang pemain yang mengontrol karakter (Tanjung, 2013).

Saat ini kebanyakan game fighting yang dikembangkan hanya sebagai sarana hiburan bagi penggunanya (Nurmanto and Gunawan, 2020). Di sisi lain, pengembangan game edukasi terkesan kaku, tidak termasuk game fighting. Ini adalah peluang yang dilihat oleh penyusun, mereka tidak hanya dapat mengembangkan game hiburan, tetapi juga game edukatif (Kurniawan, Setiawansyah and Nuralia, 2020). Bayangkan apakah sebuah game fighting penuh dengan karakter yang berbasis budaya Nusantara. Saat pengguna memainkan game tersebut, secara tidak langsung ia dapat mempelajari unsur-unsur tradisional nusantara.

\section{TELAAH PUSTAKA}

\section{Game}

Bermain merupakan bagian mutlak dari kehidupan anak-anak dan orang dewasa, dan bermain merupakan bagian penting dari pembentukan kepribadian anak (Ismail et al., 2007).

\section{D (2 Dimensi)}

Pada umumnya 2D memiliki 8 unsur dalam 2D, yaitu:

1. Titik

Segala sesuatu dalam bentuk aslinya dihasilkan dari satu titik. Dengan kata lain, titik adalah elemen terkecil yang menyusun 2D. Titik dapat menarik perhatian dengan menggunakan berbagai warna.

2. Garis

Garis dapat didefinisikan sebagai goresan atau batas objek, area, spasi, warna, tekstur, dll.

3. Lapangan

Bidang adalah elemen yang dibentuk oleh beberapa garis yang terhubung, dan dimensinya adalah panjang dan lebar.

4. Bentuk

Bentuk dibedakan menjadi dua kategori, yaitu plastik (form) dan shape (bentuk). Bentuk adalah wujud dari benda berdasarkan nilai yang dimilikinya, dan bentuk adalah wujud sebenarnya dari benda tersebut.

5. Tekstur

Tekstur adalah atribut permukaan suatu benda. Ciri-ciri permukaan benda mungkin memiliki kesan kasar, halus, berkilau, dll.

6. Warna

Salah satu metode teori warna didasarkan pada pigmen. Beberapa istilah dalam teori warna pigmen adalah warna primer, warna kedua, warna ketiga, dll.

7. Cahaya redup

Elemen terang dan gelap dalam 2D memiliki beberapa fungsi, yaitu menunjukkan kesan kedalaman, menggambarkan kesan tiga dimensi (3D), dan memberikan perbedaan kontras.

8. Ruang

Dalam bentuk 2D, jarak sangat bergantung pada bidang datar. Elemen spasial dalam 2D bersifat virtual karena tercipta melalui impresi seperti penggambaran datar, datar, dan menonjol.

\section{Construct 2}


Construct 2 merupakan salah satu alat yang dapat digunakan untuk membuat game tanpa menulis kode pemrograman, karena sebagian besar logika permainan dapat diatur melalui menu (Dwiperdana, 2013). Construct 2 adalah alat berbasis HTML5 untuk membuat game. Struktur 2 memiliki fungsi yang mudah dipahami dan digunakan oleh pemrogram pemula. HTML5 adalah bahasa markup yang dirancang untuk mengatur dan menyajikan konten untuk World Wide Web, dan itu adalah teknologi Internet inti yang awalnya diusulkan oleh perangkat lunak Opera. Construct 2 berbeda dari alat lain yang mengharuskan pemrogram menulis baris demi baris untuk membuat objek. Construct 2 didasarkan pada objek, sehingga Anda dapat dengan mudah membuat objek dan mengelola propertinya.

\section{METODE PENELITIAN \\ Kerangka Penelitian}

Kerangka penelitian merupakan suatu rancangan proses penelitian yang terstruktur, disampaikan melalui gambar yang berkesinambungan, dan dilaksanakan sesuai tahapan penelitian (Riskiono and Reginal, 2018).

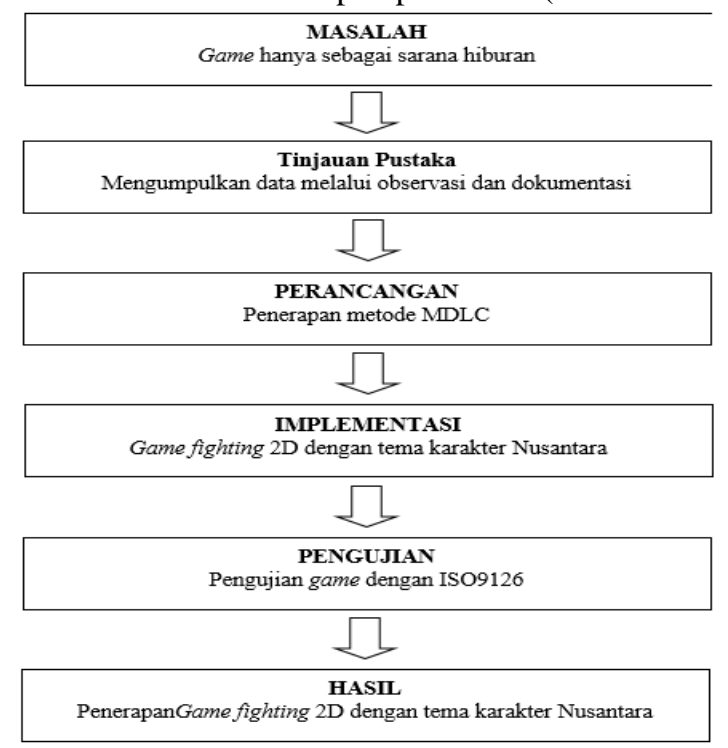

Gambar 1. Kerangka Penelitian

\section{Teknik Pengumpulan Data}

1. Observasi adalah metode pengumpulan data dengan cara mengamati objek atau fenomena yang berkaitan dengan penelitian yang sedang berlangsung. Pada penelitian ini penulis menggunakan metode observasi untuk mengamati perkembangan terbaru dalam game fighting 2D. Saat ini, aturan permainan, desain karakter dan fungsi yang disediakan di setiap game pertarungan populer dapat menjadi sumber informasi penting untuk mendesain game pertarungan 2D.

2. Dokumentasi adalah metode pengumpulan data melalui dokumen tertulis atau elektronik. Penulis mengumpulkan beberapa jurnal terkait topik sebagai sumber data (Purnama, Megawaty and Fernando, 2018).

\section{HASIL DAN PEMBAHASAN}

\section{Perancangan Menggunakan Metode MDLC}

Penyusun menggunakan metode MDLC untuk mengembangkan software game pada penelitian ini. Metode ini terdiri dari 6 tahap, yaitu concept, design, material collecting, assembly, testing dan distribution

\section{a. Concept}

Penelitian ini bertujuan untuk merancang sebuah game fighting yang memiliki nilai edukasi sehingga aspek hiburan dan pengetahuan yang didapat user menjadi seimbang. Nilai edukasi yang diambil pada penelitian ini adalah pengenalan pakaian dan senjata adatdari 10 provinsi di pulau Sumatra. Untuk memenuhi tujuan tersebut, maka penyusun telah menentukan konsep cerita dalam game ini, yaitu menceritakan kisah seorang pemuda bernama Bara yang merasa prihatin melihat adat budaya Nusantara yang mulai dilupakan oleh masyarakatnya sendiri. Ia memiliki keinginan untuk membangkitkan kembali adat budaya Nusantara. Untuk dapat mewujudkan keinginannya tersebut, 
Bara diharuskan melakukan perjalanan ke 10 provinsi di pulau Sumatra untuk melawan pasukan leluhur yang menjaga pakaian dan senjata adat setiap provinsi. Bara pun bertarung mengalahkan seluruh pasukan leluhur untuk membuktikan bahwa dirinya layak mewarisi pakaian dan senjata adat dari setiap provinsi sehingga ia dapat membangkitkan kembali adat budaya Nusantara.

\section{b. Design}

Penyusun mendesain beberapa karakter yang menjadi fokus dalam game ini, yaitu tokoh utama, pasukan musuh dan bos musuh. Setiap karakter dibuat menggunakan CorelDraw X7.

Tokoh utama dalam game ini adalah seorang pemuda bernama Bara, yang melakukan perjalanan ke 10 provinsi di pulau Sumatra untuk mewarisi pakaian dan senjata adat yang sudah mulai dilupakan. Desain tokoh utama terdiri dari 10 tampilan karakter utama yang menggunakan pakaian dan senjata adat dari 10 provinsi di pulau Sumatra.

Tabel 1. Karekter Tokoh Utama

\begin{tabular}{|c|c|c|c|}
\hline No. & Nama Karakter & Kategori Karakter & Desain Karakter \\
\hline 1 & Tokoh utama berpakaian putih & Tokoh utama & \\
\hline 2 & Bara berpakaian adat Aceh & Tokoh utama & \\
\hline 3 & $\begin{array}{l}\text { Bara berpakaian adat Sumatra } \\
\text { Utara }\end{array}$ & Tokoh utama & \\
\hline 4 & $\begin{array}{l}\text { Bara berpakaian adat Sumatra } \\
\text { Barat }\end{array}$ & Tokoh utama & \\
\hline 5 & Bara berpakaian adat Riau & Tokoh utama & \\
\hline 6 & $\begin{array}{l}\text { Bara berpakaian adat Kepulauan } \\
\text { Riau }\end{array}$ & Tokoh utama & \\
\hline 7 & Bara berpakaian adat Jambi & Tokoh utama & \\
\hline 8 & Bara berpakaian adat Bengkulu & Tokoh utama & \\
\hline
\end{tabular}




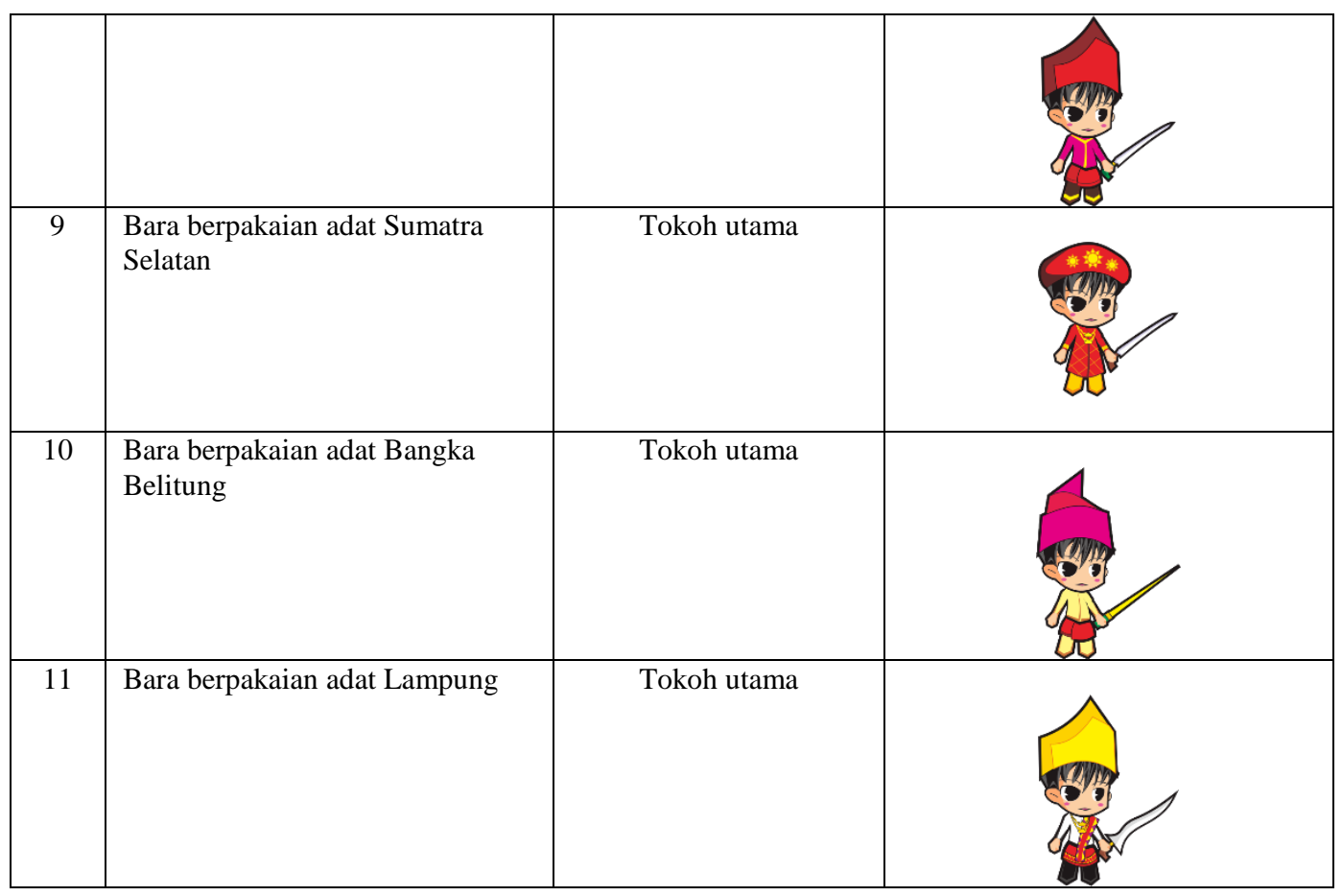

Merupakan karakter pasukan musuh yang harus dikalahkan oleh Bara sebagai tokoh utama sebelum bertemu dengan bos musuh

\begin{tabular}{|c|l|c|c|}
\hline No. & \multicolumn{1}{|c|}{ Nama Karakter } & Kategori Karakter \\
\hline 1 & $\begin{array}{l}\text { Pasukan musuh berpakaian adat } \\
\text { Aceh }\end{array}$ & Pasukan musuh \\
\hline 2 & $\begin{array}{l}\text { Pasukan musuh berpakaian adat } \\
\text { Sumatra Utara }\end{array}$ & Pasukan musuh & Desain Karakter \\
\hline 3 & $\begin{array}{l}\text { Pasukan musuh berpakaian adat } \\
\text { Sumatra Barat }\end{array}$ & Pasukan musuh & \\
\hline 4 & $\begin{array}{l}\text { Pasukan musuh berpakaian adat } \\
\text { Riau }\end{array}$ & Pasukan musuh & \\
\hline
\end{tabular}




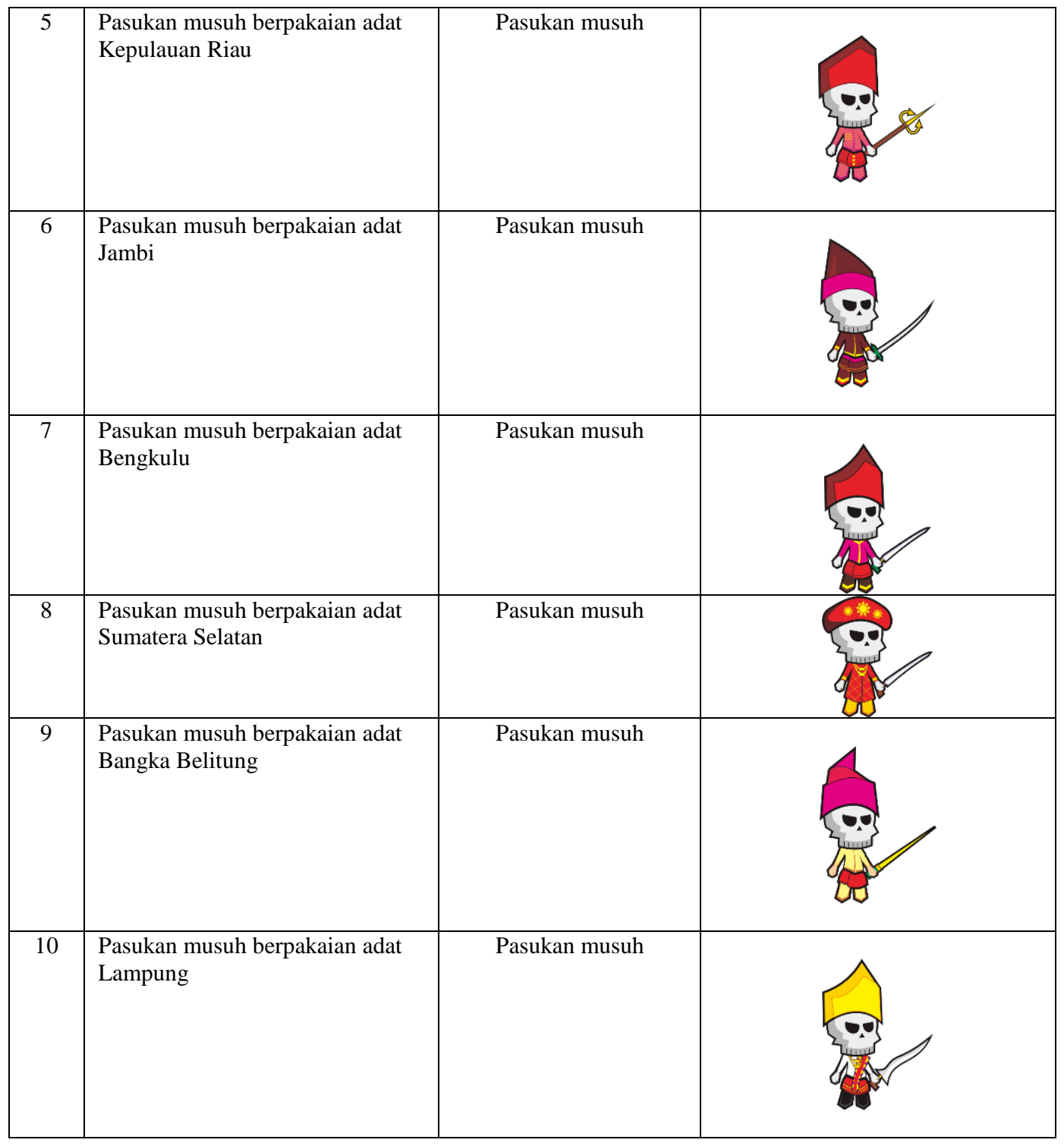

\section{c. Material Collecting}

Penyusun telah mengumpulkan file-file audio yang dibutuhkan dalam penelitian ini dari beberapa situs penyedia file audio free license.

Tabel 3. Daftar File Audio dan Sumbernya

\begin{tabular}{|c|c|c|c|}
\hline No. & Nama File & Sumber & Kegunaan \\
\hline 1 & BattlePlan.wav & www.purple-planet.com & Backsound game \\
\hline 2 & 387935_whatthes_tap1.wav & www.freesound.org & Sound effect saat menekan tombol \\
\hline 3 & $\begin{array}{c}\text { 180828_32cheeseman32_swordcl } \\
\text { ash09.wav }\end{array}$ & www.freesound.org & Sound effect tebasan senjata \\
\hline 4 & 128227_trettfilms_injured- & www.freesound.org & $\begin{array}{c}\text { Sound effect saat karakter pemain } \\
\text { terluka }\end{array}$ \\
\hline 5 & $\begin{array}{c}\text { 128227_trettfilms_injured- } \\
\text { grunts.wav }\end{array}$ & www.freesound.org & $\begin{array}{l}\text { Sound effect saat karakter musuh } \\
\text { dan bos musuh terluka }\end{array}$ \\
\hline 6 & $\begin{array}{c}\text { 337164_newagesoup_monster- } \\
\text { laugh.wav }\end{array}$ & www.freesound.org & Sound effect suara tawa musuh \\
\hline
\end{tabular}

\section{d. Assembly}


Tahap implementasi bagian ini dilakukan dengan menggunakan software Construct 2. ruang kerja Construct 2 meliputi dua bagian yang sangat penting dalam tahap implementasi yaitu layout dan event table. Bagian tata letak adalah tempat untuk menambahkan objek, dan tabel acara adalah tempat untuk menambahkan acara. Peristiwa adalah kondisi dan tindakan, yang berisi properti objek yang telah ditambahkan ke bagian tata letak. Fungsi panggilan dalam Konstruksi 2 hanya menggunakan pengaturan acara yang disediakan dalam aplikasi ini.

Layout splashscreen menampilkan judul game dan loading bar yang akan ditampilkan selama 20 detik sebelum pemain diarahkan menuju layout selanjutnya, yaitu layout cerita.

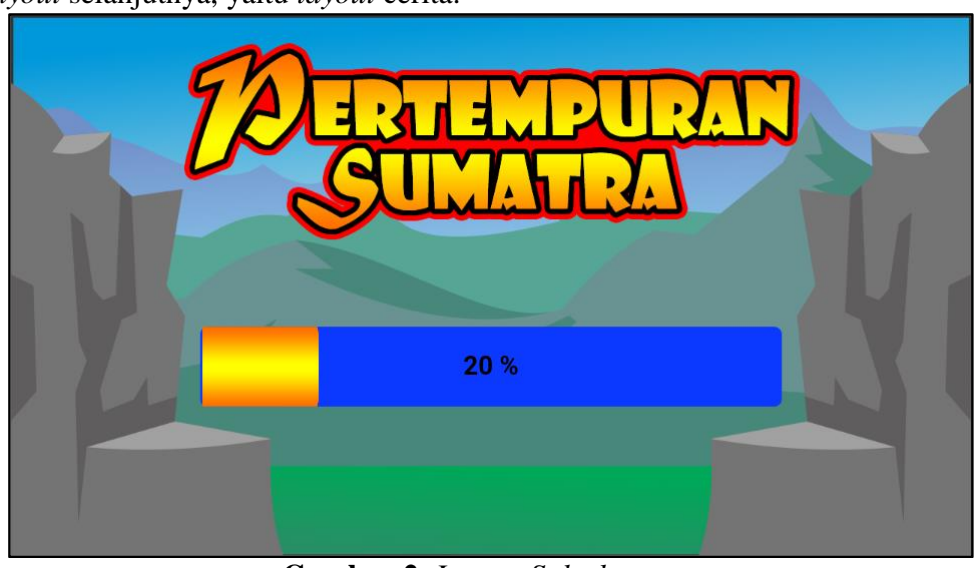

Gambar 2. Layout Splashscreen

Layout cerita menampilkan dialog yang memberikan penelasan singkat mengenai alur cerita dari game yang dirancang dalam penelitian ini. Dengan ditampilkannya alur cerita tersebut, diharapkan dapat membantu pemain untuk memahami maksud dan misi yang harus dicapai dari game ini.

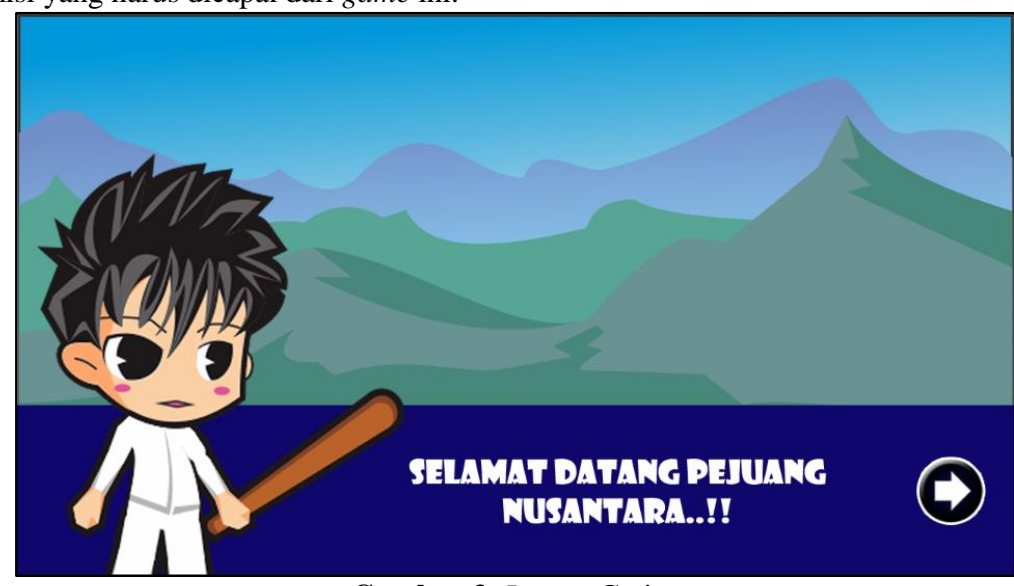

Gambar 3. Layout Cerita

Layout tampilan awal merupakan layout yang pertama kali muncul ketika user membuka software game ini. Menampilkan peta pulau Sumatra yang terdiri dari 10 provinsi, tombol scroll kanan dan kiri untuk memilih provinsi, serta tombol berikutnya untuk menuju ke layout karakter. Pada awal permainan, hanya provinsi Aceh yang dapat dipilih, sedangkan 9 provinsi lain masih terkunci. 


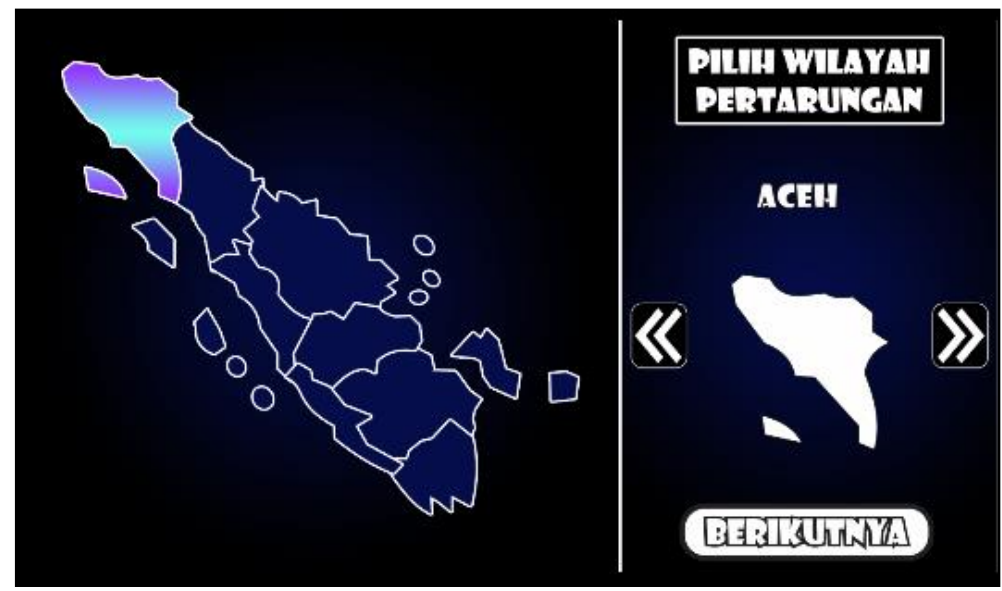

Gambar 4. Layout Tampilan Awal

Layout ini menampilkan 11 pilihan karakter pemain (1 karakter tanpa atribut adat dan 10 karakter beratribut adat). Pada saat pertama kali game ini dimainkan, hanya karakter tanpa atribut adat yang dapat dipilih. Terdapat pula tombol kembali untuk mengarahkan user kembali ke layout tampilan awal.

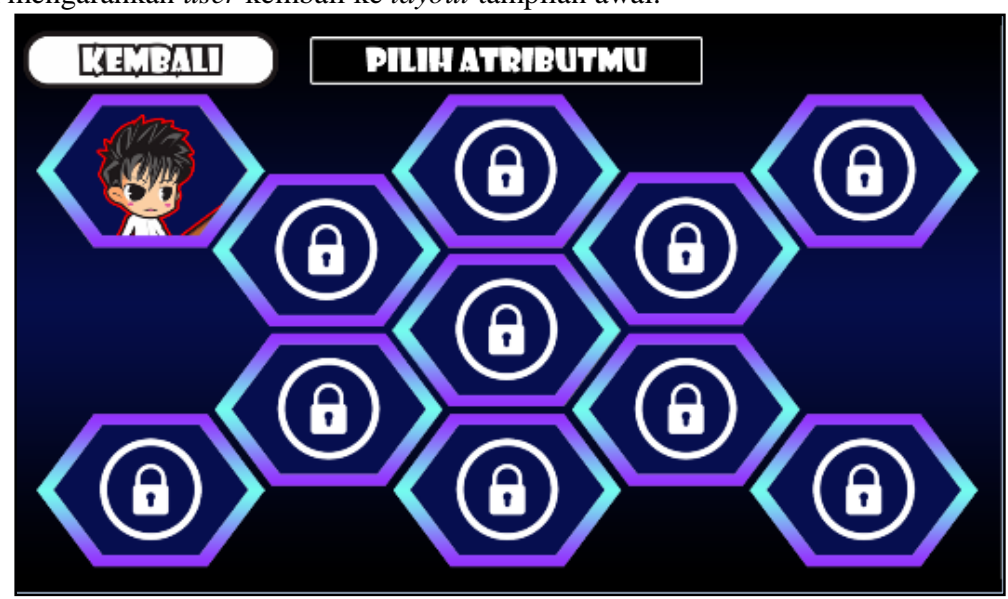

Gambar 5. Layout Karakter

Layout pertarungan merupakan layout yang menampilkan unsur fighting pada game ini. Menampilkan animasi karakter user, karakter musuh, nyawa karakter user, nyawa musuh, tombol navigasi dan tombol untuk menyerang.

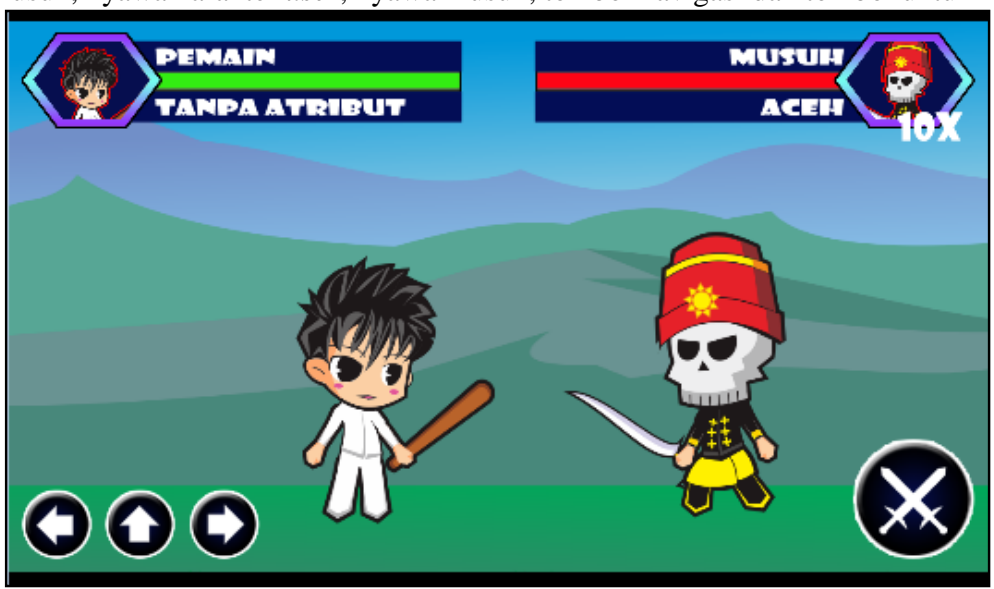

Gambar 6. Layout Pertarungan

e. Testing 
Pada tahap testing, penyusun menggunakan metode ISO 9126. Atribut kualitas software dipilih berdasarkan jenis software yang akan dikembangkan. Penyusun menggunakan faktor-faktor kualitas software tersebut sebagai acuan untuk membuat kuesioner yang telah disesuaikan dengan karakteristik software game

\section{Hasil Pengujian}

Tahap uji pada penelitian ini dilakukan dengan melibatkan 30 pengguna aplikasi yang merupakan anak-anak pada tingkat pendidikan mulai dari kelas 4 sampai dengan kelas 6 Sekolah Dasar. Pengguna aplikasi tersebut diberi kesempatan untuk mencoba software game untuk mengetahui kualitas software pada aspek functionality, efficiency, usability dan portability. Tahapan pengujian beta menggunakan bantuan kuesioner yang berisi butir-butir pertanyaan dari setiap faktor kualitas software game yang menjadi fokus penelitian. Data hasil pengujian ISO 9126 dapat dilihat pada tabel berikut

Tabel 4. Tabel Pengolahan Data Pengujian ISO 9126

\begin{tabular}{|c|c|c|c|c|}
\hline Pengguna & Functionality & Efficiency & Usability & Portability \\
\hline 1 & 10 & 15 & 5 & 10 \\
\hline 2 & 10 & 15 & 5 & 10 \\
\hline 3 & 10 & 15 & 5 & 10 \\
\hline 4 & 9 & 15 & 5 & 10 \\
\hline 5 & 10 & 15 & 5 & 10 \\
\hline 6 & 10 & 15 & 5 & 10 \\
\hline 7 & 10 & 15 & 5 & 10 \\
\hline 8 & 10 & 15 & 5 & 10 \\
\hline 9 & 10 & 15 & 5 & 10 \\
\hline 10 & 10 & 15 & 5 & 10 \\
\hline 11 & 10 & 15 & 5 & 10 \\
\hline 12 & 10 & 15 & 5 & 10 \\
\hline 13 & 10 & 15 & 5 & 10 \\
\hline 14 & 10 & 15 & 5 & 10 \\
\hline 15 & 10 & 15 & 5 & 10 \\
\hline 16 & 9 & 12 & 4 & 10 \\
\hline 17 & 10 & 15 & 5 & 10 \\
\hline 18 & 10 & 15 & 5 & 10 \\
\hline 19 & 10 & 15 & 5 & 10 \\
\hline 20 & 10 & 14 & 5 & 10 \\
\hline 21 & 10 & 15 & 5 & 10 \\
\hline 22 & 10 & 15 & 5 & 10 \\
\hline 23 & 9 & 13 & 5 & 10 \\
\hline 24 & 9 & 13 & 5 & 10 \\
\hline 25 & 10 & 15 & 5 & 10 \\
\hline 26 & 10 & 15 & 5 & 10 \\
\hline 27 & 10 & 15 & 5 & 10 \\
\hline 28 & 10 & 15 & 4 & 10 \\
\hline 29 & 10 & 15 & 4 & 10 \\
\hline 30 & 10 & 15 & 5 & 10 \\
\hline Total skor & 296 & 442 & 147 & 300 \\
\hline Skor maksimun & 300 & 450 & 150 & 300 \\
\hline Rata-rata item & 4,93 & 4,91 & 4,90 & 5,00 \\
\hline Persentase & $98,67 \%$ & $98,22 \%$ & $98,00 \%$ & $100,00 \%$ \\
\hline
\end{tabular}

Perhitungan persentase faktor kualitas software kemudian digambarkan dalam bentuk diagram. Berikut ini adalah diagram persentase faktor kualitas software pada uji beta penelitian ini : 


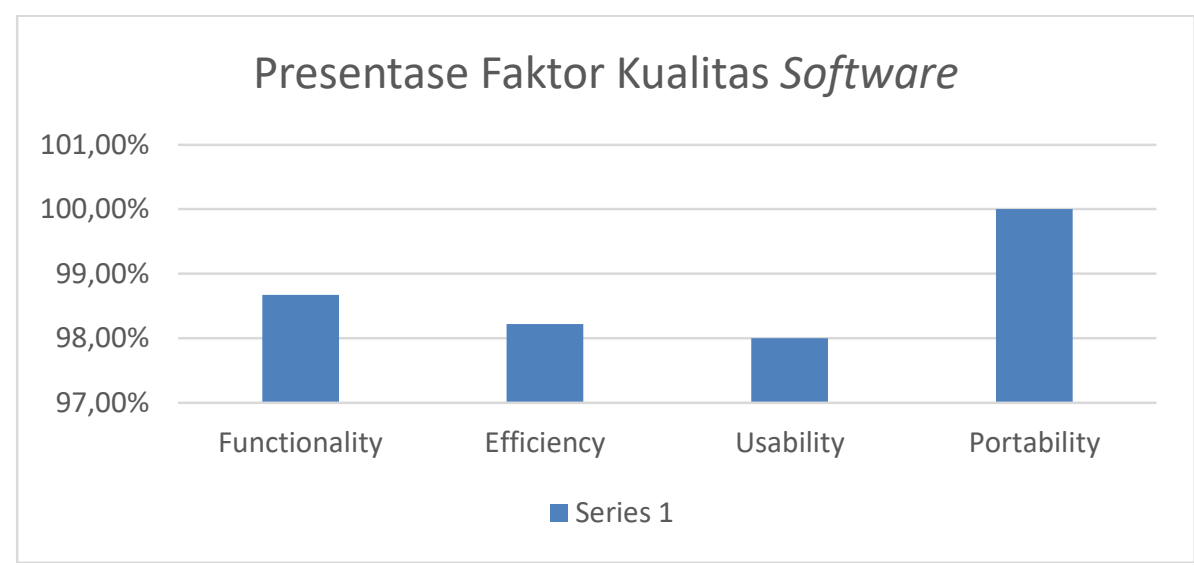

Gambar 7. Diagram Presentase Kualitas Software Pada Uji Beta

Hasil perhitungan untuk mengetahui kualitas software dari segi functionality, efficiency, usability dan portability kemudian dibandingkan dengan Interpretasi Persentase Likert. Tingkat kelayakan masing-masing faktor kualitas software setelah dibandingkan dengan tabel interpretasi persentase kelayakan software adalah sebagai berikut :

Tabel 5. Persentase Kelayakan Tiap Faktor Pada Uji Beta

\begin{tabular}{|l|l|l|l|}
\hline No. & Faktor & Presentase & Tingkat Kelayakan \\
\hline 1 & Functionality & $98,67 \%$ & Sangat Layak \\
\hline 2 & Efficiency & $98,22 \%$ & Sangat Layak \\
\hline 3 & Usability & $98,00 \%$ & Sangat Layak \\
\hline 4 & Portability & $100,00 \%$ & Sangat Layak \\
\hline
\end{tabular}

Perhitungan persentase kualitas software secara keseluruhan dari data hasil pengujian beta menggunakan rumus :

PersentaseKelayakan (\%)

$$
\begin{aligned}
& =\frac{\text { SKOR YANG DIOBSERVASI }}{\text { SKOR YANG DIHARAPKAN }} \times 100 \% \\
& =\frac{1185}{1200} \times 100 \% \\
& =98.75 \%
\end{aligned}
$$

Hasil pengolahan data pada uji beta tersebut menyatakan bahwa software game secara keseluruhan memiliki persentase kelayakan sebesar $98.75 \%$ Hasil persentase tersebut kemudian dibandingkan dengan tabel Interpretasi Persentase Likert. Hasil yang didapatkan setelah membandingkan persentase kelayakan software adalah dapat disimpulkan bahwa kualitas software game pada penelitian ini memiliki kategori "Sangat Layak".

\section{SIMPULAN}

Berdasarkan penelitian yang telah dilakukan, dapat diambil kesimpulan sebagai berikut :

1. Perancangan game fighting 2 dimensi berbasis android dapat dilakukan dengan memanfaatkan software Construct 2 .

2. Unsur pengenalan pakaian dan senjata adat dalam game ini dapat diterima dan dipahami oleh pengguna dengan mudah. Hal ini dapat dilihat dari hasil pengujian dengan menyebarkan kuesioner.

3. Nilai persentase hasil pengujian ISO 9126 untuk setiap faktor, yaitu functionality sebesar 98,67\%, efficiency sebesar $98,22 \%$, usability sebesar $98,00 \%$ dan portability sebesar 100,00\%. Persentase total dari pengujian ISO 9126 untuk kualitas software game ini adalah 98,75\% (Sangat Layak).

\section{UCAPAN TERIMA KASIH}

Puji syukur penulis panjatkan kepada Allah SWT, karena atas berkat dan rahmat-Nya, penulis dapat menyelesaikan penelitian ini. Penulisan Penulis menyadari bahwa, tanpa bantuan dan bimbingan dari berbagai pihak, dari masa perkuliahan sampai pada penyusunan penelitian ini. Oleh karena itu, penulis mengucapkan terima kasih kepada:

1. Bapak Dr.H.M. Nasrullah Yusuf S.E, M.B.A., selaku Rektor Universitas Teknokrat Indonesia;

2. Bapak Dr. H. Mahathir Muhammad, S.E., M.M., selaku Dekan Fakultas Teknik dan Ilmu Komputer, Universitas Teknokrat Indonesia; 
3. Ibu Dyah Ayu Megawaty, M. Kom. selaku Ketua Program S1 Informatika, Fakultas Teknik dan Ilmu Komputer, Universitas Teknokrat Indonesia;

\section{REFERENSI/DAFTAR PUSTAKA}

Ahdan, S. and Setiawansyah, S. (2020) 'Pengembangan Sistem Informasi Geografis Untuk Pendonor Darah Tetap di Bandar Lampung dengan Algoritma Dijkstra berbasis Android', Jurnal Sains dan Informatika: Research of Science and Informatic, 6(2), pp. 67-77.

Christiantho, D. (2017) 'Ini 8 Jenis Genre Game dan Sub Genre-nya', Ini Game.

Dwiperdana, A. (2013) ‘Construct 2: Menggerakkan karakter tanpa programming’.

Ismail, I. A. et al. (2007) ‘Game Theory Using Genetic Algorithms.', in World Congress on Engineering, pp. 61-64.

Kurniawan, I., Setiawansyah and Nuralia (2020) 'PEMANFAATAN TEKNOLOGI AUGMENTED REALITY UNTUK PENGENALAN PAHLAWAN INDONESIA DENGAN MARKER', Jurnal Informatika dan Rekayasa Perangkat Lunak, 1(1), pp. 9-16.

Nurmanto, D. and Gunawan, R. D. (2020) 'PEMANFAATAN AUGMENTED REALITY DALAM APLIKASI MAGIC BOOK PENGENALAN PROFESI UNTUK PENDIDIKAN ANAK USIA DINI’, 1(1), pp. 36-42.

Purnama, S., Megawaty, D. A. and Fernando, Y. (2018) 'Penerapan Algoritma A Star Untuk Penentuan Jarak Terdekat Wisata Kuliner di Kota Bandarlampung', Jurnal teknoinfo, 12(1), pp. 28-32.

Riskiono, S. D. and Reginal, U. (2018) 'Sistem Informasi Pelayanan Jasa Tour Dan Travel Berbasis Web (Studi Kasus Smart Tour)', Informasi Dan Komputer, 06(02), pp. 51-62.

Sintaro, S., Ramdani, R. and Samsugi, S. (2020) 'Rancang Bangun Game Edukasi Tempat Bersejarah Di’, 1(1), pp. 51-57.

Tanjung, M. A. P. (2013) ‘Analisis Pengaruh Storytelling Terhadap Game Lorong Waktu-Pangeran Diponegoro Sebagai Media Edukasi Sejarah', Jurnal Ilmiah Komputer dan Informatika (KOMPUTA). 